Research article

Open Access

\title{
Contribution of KIR3DL1/3DS1 to ankylosing spondylitis in human leukocyte antigen-B27 Caucasian populations
}

\author{
Carlos Lopez-Larrea', Miguel Angel Blanco-Gelaz', Juan Carlos Torre-Alonso², \\ Jacome Bruges Armas ${ }^{3}$, Beatriz Suarez-Alvarez'1, Laura Pruneda' ${ }^{1}$, Ana Rita Couto ${ }^{3}$, \\ Segundo Gonzalez ${ }^{4}$, Antonio Lopez-Vázquez ${ }^{1}$ and Jesus Martinez-Borra ${ }^{1}$
}

\author{
${ }^{1}$ Histocompatibility and Transplantation Unit, Hospital Universtario Central de Asturias, Celestino Villamil s/n. 33006 Oviedo, Asturias, Spain \\ ${ }^{2}$ Rheumatology Unit, Hospital Monte Naranco, Avda Dres Fernandez Vega 107. 33012 Oviedo, Asturias, Spain \\ 3Immunogenetic Service, Hospital de Santo Espirito de Angra do Heroismo, Vinha Brava. 9700 Angra do Heroismo, Azores, Portugal \\ ${ }^{4}$ Functional Biology Department, University of Oviedo, Avda Julian Claveria s/n. 33006 Oviedo, Asturias, Spain \\ Corresponding author: Carlos Lopez-Larrea, inmuno@hca.es
}

Received: 10 Mar 2006 Revisions requested: 23 Mar 2006 Revisions received: 5 Apr 2006 Accepted: 5 Jun 2006 Published: 28 Jun 2006

Arthritis Research \& Therapy 2006, 8:R101 (doi:10.1186/ar1988)

This article is online at: http://arthritis-research.com/content/8/4/R101

(C) 2006 López-Larrea et al.; licensee BioMed Central Ltd.

This is an open access article distributed under the terms of the Creative Commons Attribution License (http://creativecommons.org/licenses/by/2.0), which permits unrestricted use, distribution, and reproduction in any medium, provided the original work is properly cited.

\begin{abstract}
Killer cell immunoglobulin-like receptors (KIRs) and human leukocyte antigen (HLA) loci are both highly polymorphic, and some HLA class I molecules bind and trigger cell-surface receptors specified by KIR genes. We examined whether the combination of KIR3DS1/3DL1 genes in concert with HLA-B27 genotypes is associated with susceptibility to ankylosing spondylitis (AS). Two HLA-B27-positive Caucasian populations were selected, one from Spain (71 patients and 105 controls) and another from the Azores (Portugal) ( 55 patients and 75 controls). All were typed for HLA-B and KIR (3DS1 and $3 D L 1)$ genes. Our results show that in addition to B27, the allele $3 D S 1$ is associated with AS compared with B27 controls $(p<0.0001$ and $p<0.003$ in the Spanish population and Azoreans, respectively). We also observed that the association of KIR3DS1 to AS was found in combination with HLA-B alleles
\end{abstract}

carrying Bw4-180 in trans position in the Spanish population (30.9\% in AS versus $15.2 \%$ in B27 controls, $p=0.02$, odds ratio $(O R)=2.49)$ and in Azoreans $(27.2 \%$ in $A S$ versus $8.7 \%$ in B27 controls, $p=0.01$, OR $=4.4$ in Azoreans). On the other hand, 3DL1 was decreased in patients compared with B27 controls $(p<0.0001$ in the Spanish population and $p<0.003$ in Azoreans). The presence of this allele in combination with Bw4-180 had a protective effect against the development of AS in the Spanish population (19.7\% in AS, 35.2\% in B27 controls; $p=0.03, \mathrm{OR}=0.45)$. The presence of $K I R 3 D S 1$ or $K I R 3 D L 1$ in combination with HLA-B*27s/HLA-B Bw4-180 genotypes may modulate the development of AS. The susceptibility to AS could be determined by the overall balance of activating and inhibitory composite KIR-HLA genotypes.

\section{Introduction}

The association of ankylosing spondylitis (AS) with human leukocyte antigen (HLA)-B27 has been demonstrated worldwide, and evidence for the role of HLA-B27 in AS comes from linkage and association studies in humans and transgenic animal models. However, twin studies indicate that HLA-B27 contributes only $16 \%$ of the total genetic risk for disease [1]. Genome-wide scans have implicated regions on chromosomes 2q, 6p, 6q, 10q, 11q, 16q, 17q, and 19q in AS [2,3]. The killer immunoglobulin-like receptor (KIR) genes encode a group of proteins that are expressed on natural killer (NK) cells and in some T cells that are located on chromosome 19q13.4 in the leukocyte receptor complex (reviewed in [4]). KIR proteins act as receptors that recognise major histocompatibility complex (MHC) class I molecules and are directly involved in the activation and inhibition of NK and possibly also in $\mathrm{CD}^{+} \mathrm{T}$ cells $[5,6]$.

Given the receptor-ligand relationship between certain combinations of KIR and HLA class I molecules, it is reasonable to

AS = ankylosing spondylitis; $\mathrm{HC}=$ heavy chain; $\mathrm{HLA}=$ human leukocyte antigen; $\mathrm{HWE}=$ Hardy-Weinberg equilibrium; ILT = immunoglobulin-like lymphocyte T receptors; KIR = killer cell immunoglobulin-like receptor; $\mathrm{MHC}=$ major histocompatibility complex; $\mathrm{NK}=$ natural killer; $\mathrm{NKR}=$ natural killer receptor; $\mathrm{OR}=$ odds ratio; $\mathrm{PCR}=$ polymerase chain reaction; $\mathrm{SSO}=$ sequence-specific oligoprobe; $\mathrm{SSP}=$ sequence-specific primer; $\mathrm{TCR}=$ T-cell receptor. 
hypothesise a synergistic relationship between these polymorphic loci. This could be the case of the KIR3DL1 inhibitory receptor, the only KIR known to recognise HLA-B alleles. It binds to HLA-B with serological-defined epitope Bw4 (determined by amino acid positions 79-83 of the molecule) [7] with an isoleucine at position 80 (Bw4-180) [8]. The interaction of KIR3DL1 and Bw4-I80 has an inhibitory effect on the cytotoxic capacity of NK cells. All HLA-B27 subtypes carry Bw4 epitope, with the exception of $B^{\star} 2708$ and other related subtypes, which carry Bw6. From those with Bw4, $B^{\star} 2702$ is the only subtype with an isoleucine at position 80 (Bw4-180). The differences between the activating receptor KIR3DS1 and the inhibitory 3DL1 are located in the intracytoplasmic tail. The inhibitory receptor has a long tail containing immunoreceptor tyrosine inhibitory motifs, whereas the activating receptor has a short tail without this motif but with the capacity to interact with activating adaptor proteins such as DAP12 [9]. The ligand for KIR3DS1 has not been determined, although it has been shown that the KIR3DS1 activating receptor in combination with HLA-B alleles that encode molecules with isoleucine at position 80 (HLA-B Bw4-I80) results in delayed progression to AIDS after HIV-1 infection [10]. Recent studies have also reported a strong association of KIR/HLA combinations in the development of psoriatic arthritis [11].

The aim of this study was to analyse whether KIR3DL1 and $3 D S 1$ genes, and their possible synergistic effect with HLA-B alleles, influence the susceptibility to AS in HLA-B27-positive individuals.

\section{Materials and methods Patients and controls}

Two B27-positive Caucasians populations were selected for this study, one from Spain (71 patients with AS and 105 healthy matched controls) and another from the Azores (Portugal) (55 patients with AS and 57 healthy matched controls). The patients with AS were diagnosed at the rheumatology units of the Hospital Universtario Central de Asturias and Hospital Naranco, Oviedo, Asturias, Spain, and the Rheumatic Diseases Clinic of the Angra do Heroismo Hospital, Azores, in accordance with New York criteria [12]. Radiographs of the pelvis and lumbar spine were obtained in all patients. Sacroiliac joint changes were determined on the basis of the New York criteria. All patients had sacroiliitis bilateral grade II or more. Both patients and controls gave written informed consent prior to enrolling in the study. The protocol was approved by the ethics committees of our hospitals and conducted according to the Declaration of Helsinki.

B27 subtypes were determined by polymerase chain reaction (PCR) using sequence-specific primer (SSP) as described previously [13]. HLA-B alleles and Bw4 and Bw6 epitopes were typed by PCR-sequence-specific oligoprobes (SSOs) with RELI ${ }^{\mathrm{TM}}$-SSO typing kits (Dynal Biotech, Oslo, Norway). $K I R 3 D L 1$ and $3 D S 1$ genotyping was performed by PCR with gene-specific primer pairs in accordance with the method previously described [14]. Both were considered as alleles from the same locus.

Allelic frequencies were calculated by direct counting, and the significance of the association was determined using the $\chi^{2}$ test with Yate's correction or Fisher's exact test. The odds ratio $(\mathrm{OR})$ was calculated by the cross-product ratio. Exact confidence intervals of $95 \%$ were obtained. The $\chi^{2}$ test was used for Hardy-Weinberg equilibrium (HWE) by comparing the observed number of subjects for each genotype with the expected number of subjects, assuming the existence of HWE.

\section{Results and Discussion}

Here, we have analysed the possible influence of KIR genotypes in the susceptibility to AS in B27 individuals. The study was undertaken in two genetically distinct Caucasian populations but with a slightly different distribution of B27 alleles $[15,16]$.

HLA-B27 represents a family of at least 27 closely related alleles $\left(B^{\star} 2701-27\right)$ that differ in their ethnic distribution. We used an SSP typing approach (PCR-SSP) capable of allelic detection of all B27 alleles described at present. The B27 alleles detected in our study can be classified into two categories: one group of alleles over-represented $\left(B^{\star} 2705,02\right)$ and another group of alleles with minor representation such as $B \star 2703, B \star 2707, B \star 2708$, and $B * 2713$. No differences were found in the distribution of B27 subtypes among patients with AS and B27-positive matched controls in either the Spanish or Azorean populations. We found some alleles that are present only in the Azorean population, such as $B^{\star} 2703$ and $B^{\star} 2708$, whereas we only found one individual with $B^{\star} 2713$ in the Spanish population (Table 1).

However, differences in the distribution of the KIR3DS1 allele were found among these groups in both populations (Table 2). This allele was over-represented in the AS group compared with B27-positive healthy controls $(42.9 \%$ versus $22.3 \%, p<$ $0.0001, \mathrm{OR}=2.6$ in the Spanish population and $35.4 \%$ versus $17.5 \%, p<0.003$, OR $=2.58$ in Azoreans). We also found a different distribution of the KIR $3 D L 1$ frequency among the groups because this gene and KIR3DS1 segregate as alleles. KIR3DL1 was found to be decreased in patients with AS compared with B27-positive controls (57\% versus $77.6 \%$, $p<0.0001, \mathrm{OR}=0.3$ in the Spanish population and $64.5 \%$ versus $82.4 \%, p<0.003, \mathrm{OR}=0.38$ in Azoreans). Both alleles were also distributed differently when we considered the homozygous genotypes. $3 D L 1 / 3 D L 1$ was increased in B27positive controls $(p=0.0008, \mathrm{OR}=0.33$ in the Spanish population and $p<0.001, \mathrm{OR}=0.26$ in Azoreans) compared with patients with AS. On the other hand, the $3 D S 1 / 3 D S 1$ genotype was increased in patients with AS compared with B27 controls, although in the Azorean population this was not 
Table 1

Distribution of B27 subtypes in patients with ankylosing spondylitis (AS) and controls in Spanish and Azorian populations

\begin{tabular}{|c|c|c|c|c|}
\hline \multirow[b]{2}{*}{ Subtypes } & \multicolumn{2}{|c|}{ Spanish } & \multicolumn{2}{|c|}{ Azorian } \\
\hline & Patients with AS $(n=71)$ & Controls $(n=105)$ & Patients with AS $(n=55)$ & Controls $(n=57)$ \\
\hline$B^{\star} 2705$ & $68(95.7 \%)$ & $94(89.5 \%)$ & $45(81.8 \%)$ & $52(91.2 \%)$ \\
\hline$B^{\star} 2702$ & $3(4.3 \%)$ & $9(8.6 \%)$ & 7 (12.7\%) & $2(3.5 \%)$ \\
\hline$B^{\star} 2703$ & - & - & - & 2 (3.5\%) \\
\hline$B^{\star} 2707$ & - & $1(0.95 \%)$ & - & $1(1.8 \%)$ \\
\hline$B^{\star} 2708$ & - & - & 3 (5.5\%) & - \\
\hline $\mathrm{B}^{\star} 2713$ & - & $1(0.95 \%)$ & - & - \\
\hline
\end{tabular}

significant with the size of the sample studied $(p=0.0009$, OR $=3.75$ in the Spanish population). When both genotypes are present $(3 D S 1 / 3 D L 1)$, the activating effect appears to be prevailing and so this genotype is increased in patients in both populations, significantly in Azoreans $(p=0.005)$. No deviation from the HWE was detected in either patients or controls.

Finally, we analysed whether the Bw4-I80 ligand is involved in the susceptibility of KIR3DS1 to AS. We classified the HLA-B alleles of the subjects studied according to the presence of Bw4/Bw6 serological epitopes. The incidence of the B27 genotypes with HLA-B alleles in trans position with a Bw4-180 (or in cis when the allele is $B^{\star} 2702$ ) was not found to be different in patients with AS and both control groups. However, we found these two factors to be combined (3DS1/B27 genotypes with Bw4-180 in trans) in 30.95\% of patients with AS and in only $15.2 \%$ of B27-positive controls in the Spanish population ( $p=0.02$, OR $=2.49$ ) and in $27.2 \%$ of patients with AS and in 8.7\% of B27-positive controls in Azoreans ( $p$ $=0.01$, OR = 4.4). Moreover, the inhibitory 3DL1/Bw4-180 genotype was found to be increased in the control group compared with patients with AS in both populations, although not significantly in the Azorean population, possibly due to the size of the population.

Thus, the attributable effect of KIR3DL1 (protection) or 3DS1 (susceptibility) on AS susceptibility may be more effective when the corresponding ligand Bw4-180 is present and the effects could be additional to the presence of $H L A-B^{\star} 27$. The presence of one single additional HLA-B allele carrying the Bw4-180 epitope in $B^{\star} 27$-positive individuals could modulate the state of cell activation of NK (and/or T) cells in conjunction with the pattern of KIR gene expression.

$K I R 3 D L 1$ and $3 D S 1$ genes are polymorphic, and in the case of $K I R 3 D L 1$ it has been described that this polymorphism may influence the expression [17] or the inhibitory effect [18] of the different alleles. This fact could also be important for the role of these genes in the susceptibility to AS.
The mechanism by which HLA-B27 confers susceptibility to inflammatory AS is not understood but is presumed to involve some unique aspect of its role in antigen presentation (reviewed in [19]). It has been argued that the T-cell response to an arthritogenic peptide(s) of endogenous origin and bound by HLA-B27 molecules might be the cause of spondyloarthropathies. In addition to their classical antigen-presenting role, it has been described that HLA-B27 are recognised by members of the KIR and leukocyte immunoglobulin-like receptor (ILT) families in both human and animal models. Members of KIR (3DL1 and 3DL2) and ILT (ILT4) are able to bind B27 in both classical $\beta 2 \mathrm{~m} /$ heavy chain $(\mathrm{HC})$ and $\beta 2 \mathrm{~m}$-free $\mathrm{HC}$ homodimers (HC-B27) that are dependent on the presence of Cys67 of the B27 molecule [20-22]. It has been argued that alternative recognition of different forms of HLA-B27 by KIR or ILT could influence their immunomodulatory function and may imply a role in inflammatory disease.

Binding of the KIR3DL1 receptor to the Bw4 family of MHC class I receptors has been shown to be dependent on key residues of the $\mathrm{HC}$ around isoleucine 80 [8]. However, it has been described that HLA-B*2705, which carries a Bw4 epitope containing threonine at residue 80 , is also recognised by KIR3DL1, this interaction being peptide-specific [23]. In fact, it has been shown that KIR3DL1 recognises HLA-B27 molecules when loaded with a self-peptide and with a number of viral non-self-peptides. Nevertheless, some viral peptides such as EBV EBNA3C 258-266, which bind to HLA-B*2705, block the NK inhibitory receptor 3DL1 [24]. Anchor residues at position P7 and P8 of some viral peptides may prevent KIR3DL1-mediated recognition of HLA-B27. Similarly, it is probable that a significant fraction of $B^{\star} 27$ 'arthritogenic' ligands fail to interact with KIR3DL1 during the course of microbial infection, which thereby influences the activation of activating NK receptors (NKRs) (3DS1 and others) and subsequent progression to $A S$. It is therefore plausible that the presence of another HLA-B allele carrying the Bw4-180 epitope may antagonise the unfavourable interaction of KIR3DL1 with an HLA-B27-peptide. 
Table 2

Allelic and genotypic frequencies of KIR and HLA-B Bw4-180 in patients with AS and B27 healthy controls in Spanish and Azorian populations.

\begin{tabular}{|c|c|c|c|c|c|c|c|c|}
\hline Genotypes & $\begin{array}{c}\text { Spanish AS } \\
(2 n=142)\end{array}$ & $\begin{array}{c}\text { Spanish controls } \\
(2 n=210)\end{array}$ & $p$ & OR $(95 \% \mathrm{Cl})$ & $\begin{array}{c}\text { Azorean AS } \\
(2 n=110)\end{array}$ & $\begin{array}{c}\text { Azorean controls } \\
\quad(2 n=114)\end{array}$ & $p$ & OR $(95 \% \mathrm{Cl})$ \\
\hline $3 D S 1$ & $61(42.9 \%)$ & $47(22.3 \%)$ & $<0.0001$ & $2.6(1.64-4.15)$ & $39(35.4 \%)$ & $20(17.5 \%)$ & $<0.003$ & $2.58(1.38-4.8)$ \\
\hline $3 D L 1$ & $81(57 \%)$ & $163(77.6 \%)$ & $<0.0001$ & $0.3(0.24-0.6)$ & $71(64.5 \%)$ & $94(82.4 \%)$ & $<0.003$ & $0.38(0.2-0.72)$ \\
\hline Bw4180 & $24(16.9 \%)$ & $40(19 \%)$ & NS & - & $18(16.3 \%)$ & $17(14.9 \%)$ & NS & - \\
\hline Genotypes & $\begin{array}{c}\text { Spanish AS } \\
(n=71)\end{array}$ & $\begin{array}{c}\text { Spanish controls } \\
(n=105)\end{array}$ & & & $\begin{array}{c}\text { Azorean AS } \\
(n=55)\end{array}$ & $\begin{array}{l}\text { Azorean controls } \\
\quad(n=57)\end{array}$ & & \\
\hline $3 D L 1 / 3 D L 1$ & $25(35.2 \%)$ & $65(61.9 \%)$ & 0.0008 & $0.33(0.17-0.62)$ & $20(36.3 \%)$ & $39(68.4 \%)$ & $<0.001$ & $0.26(0.12-0.57)$ \\
\hline $3 D S 1 / 3 D S 1$ & $15(21.1 \%)$ & $7(6.6 \%)$ & 0.0009 & $3.75(1.44-9.74)$ & $4(7.2 \%)$ & 2 (3.5\%) & NS & - \\
\hline $3 D S 1 / 3 D L 1$ & $31(43.6 \%)$ & $33(31.4 \%)$ & NS & - & $31(56.1 \%)$ & $16(28 \%)$ & 0.005 & $3.3(1.50-7.26)$ \\
\hline $3 D S 1 / B w 4180+$ & $22(30.9 \%)$ & $16(15.2 \%)$ & 0.02 & $2.49(1.2-5.19)$ & $15(27.2 \%)$ & $5(8.7 \%)$ & 0.01 & $4.4(1.48-13.37)$ \\
\hline $3 D S 1 / \mathrm{Bw} 4180-$ & 24 (33.8\%) & $24(22.8 \%)$ & NS & - & $20(36.3 \%)$ & $13(22.8 \%)$ & NS & - \\
\hline $3 D L 1 / \mathrm{Bw} 4180+$ & $14(19.7 \%)$ & $37(35.2 \%)$ & 0.03 & $0.45(0.22-0.91)$ & $9(16.3 \%)$ & $16(28 \%)$ & NS & - \\
\hline 3DL1/Bw4I80 - & $42(59.1 \%)$ & $61(58.1 \%)$ & NS & - & $36(64.4 \%)$ & $39(68.4 \%)$ & NS & - \\
\hline
\end{tabular}

AS, ankylosing spondylitis; $\mathrm{Cl}$, confidence interval; HLA, human leukocyte antigen; KIR, killer cell immunoglobulin-like receptor; NS, not significant; OR, odds ratio.

NKRs are expressed on subsets of effector and memory $\mathrm{T}$ cells [25]. It has previously been shown that stimulatory KIRs are able to promote proliferative responses of CD28null T-cell clones, suggesting that the recognition of self-MHC class I molecules may lead to clonal expansion [26]. In a similar way to CD28, KIR receptors may function as T-cell receptor (TCR) co-stimulatory molecules. Interestingly, circulating effectors of CD4+CD28null and CD8 ${ }^{+}$CD28null $T$ cells were found to be expanded in AS and associated with more severe joint restrictions $[27,28]$. Expression of NKRs, including various members of the KIR family, was found on CD4+CD28null $T$ cells in patients with $A S$, and this resembles that found in rheumatoid arthritis [29,30].

The existence of a high degree of heterogeneity has been described in the expression of NKR by intrasynovial CD8 ${ }^{+} \mathrm{T}$ cells that could modulate their cytotoxicity and play a role in the control of this HLA class I-associated autoimmune disease [31]. The activating KIR3DS1 in CD28nullT cells could provide a mechanism through which TCR could be involved in enhancing and extending the immune response in AS, lowering the activation threshold for these cells, irrespective of their antigen specificity. The expression of KIR3DL1 may serve as a mechanism to control the activity of self-reactive $T$ cells induced by arthritogenic peptides presented by $\beta 2 \mathrm{~m} / \mathrm{HC}$ or $\mathrm{HC}-\mathrm{B} 27$, thus mediating T-cell tolerance to self-antigens. The genetic imbalance between KIR and their HLA class I ligands may enhance the activation of $T$ cells with a low affinity for joint self-antigens, thereby contributing to the pathogenesis of AS.

\section{Conclusion}

The presence of KIR3DS1 or KIR3DL1 in combination with HLA-B*27s/HLA-B Bw4-180 genotypes may modulate the development of AS. The susceptibility to AS could be determined by the overall balance of activating and inhibitory composite KIR-HLA genotypes. Further analysis of NKR expression on T cells in patients with AS may help to elucidate the role of KIR receptor in predisposing to disease.

\section{Competing interests}

The authors declare that they have no competing interests.

\section{Authors' contributions}

$\mathrm{CL}$ conceived the study, participated in its design and coordination, and helped to draft the manuscript. JCT and JBA participated in the design of the study and in the selection of the patients. MAB, BS, LP, and ARC carried out the molecular genetic studies. SG participated in drafting the manuscript. AL participated in the design of the study and performed the statistical analysis. JM participated in the design of the study, carried out the molecular genetic studies, and participated in the statistical analysis. All authors read and approved the final manuscript.

\section{Acknowledgements}

This work was supported in part by the Spanish Ministry of Education and Science (grant SAF2004-02669). JM was supported in part by the Spanish Post-MIR program from 'Fondo de Investigación Sanitaria'. We thank David H. Wallace for critical revision of the manuscript.

\section{References}

1. Sims AM, Wordsworth BP, Brown MA: Genetic susceptibility to ankylosing spondylitis. Curr Mol Med 2004, 4:13-20. 
2. Brown MA, Pile KD, Kennedy LG, Campbell D, Andrew L, March R, Shatford JL, Weeks DE, Calin A, Wordsworth BP: A genomewide screen for susceptibility loci in ankylosing spondylitis. Arthritis Rheum 1998, 41:588-595.

3. Laval SH, Timms A, Edwards S, Bradbury L, Brophy S, Milicic A, Rubin L, Siminovitch KA, Weeks DE, Calin A, et al:: Wholegenome screening in ankylosing spondylitis: evidence of nonMHC genetic-susceptibility loci. Am J Hum Genet 2001, 68:918-926.

4. Vilches C, Parham P: KIR: diverse, rapidly evolving receptors of innate and adaptive immunity. Annu Rev Immunol 2002, 20:217-251.

5. D'Andrea A, Chang C, Phillips JH, Lanier LL: Regulation of T cell lymphokine production by killer cell inhibitory receptor recognition of self HLA class I alleles. J Exp Med 1996, 184:789-794.

6. Vivier $\mathrm{E}$, Anfossi N: Inhibitory NK-cell receptors on T cells: witness of the past, actors of the future. Nat Rev Immunol 2004, 4:190-198.

7. Gumperz JE, Litwin V, Phillips JH, Lanier LL, Parham P: The Bw4 public epitope of HLA-B molecules confers reactivity with natural killer cell clones that express NKB1, a putative HLA receptor. J Exp Med 1995, 181:1133-1144.

8. Cella M, Longo A, Ferrara GB, Strominger JL, Colonna M: NK3specific natural killer cells are selectively inhibited by Bw4positive HLA alleles with isoleucine 80. J Exp Med 1994, 180:1235-1242.

9. Lanier LL, Corliss BC, Wu J, Leong C, Phillips JH: Immunoreceptor DAP12 bearing a tyrosine-based activation motif is involved in activating NK cells. Nature 1998, 391:703-707.

10. Martin MP, Gao X, Lee JH, Nelson GW, Detels R, Goedert JJ, Buchbinder S, Hoots K, Vlahov D, Trowsdale J, et al:: Epistatic interaction between KIR3DS1 and HLA-B delays the progression to AIDS. Nat Genet 2002, 31:429-434.

11. Martin MP, Nelson G, Lee JH, Pellett F, Gao X, Wade J, Wilson MJ, Trowsdale J, Gladman D, Carrington M: Cutting edge: susceptibility to psoriatic arthritis: influence of activating killer Ig-like receptor genes in the absence of specific HLA-C alleles. $J$ Immunol 2002, 169:2818-2822.

12. Van der Linden $S$, Valkenburg HA, Cats A: Evaluation of diagnostic criteria for ankylosing spondylitis. A proposal for modification of the New York Criteria. Arthritis Rheum 1984, 27:361-368.

13. García-Fernández S, González S, Miña Blanco A, Martínez-Borra J, Blanco-Gelaz MA, López-Vazquez A, López-Larrea C: New insights regarding HLA-B27 diversity in the Asian population. Tissue Antigens 2001, 58:259-262.

14. Gómez-Lozano N, Vilches C: Genotyping of human killer-cell immunoglobulin-like receptor genes by polymerase chain reaction with sequence-specific primers. An update. Tissue Antigens 2002, 59:184-193.

15. Armas JB, González S, Martínez-Borra J, Laranjeira F, Ribeiro E, Correia J, Ferreira ML, Toste M, López-Vazquez A, López-Larrea C: Susceptibility to ankylosing spondylitis is independent of the Bw4 and Bw6 epitopes of HLA-B27 alleles. Tissue Antigens 1999, 53:237-243.

16. González S, Garcia-Fernandez S, Martínez-Borra J, Blanco-Geláz MA, Rodrógo L, Sanchez del Río J, López-Vázquez A, Torre-Alonso JC, López-Larrea C: High variability of HLA-B27 alleles in ankylosing spondylitis and related spondyloarthropathies in the population of northern Spain. Hum Immuno/ 2002, 63:673-676.

17. Pando MJ, Gardiner CM, Gleimer M, McQueen KL, Parham P: The protein made from a common allele of KIR 3DL1 (3DL1*004) is poorly expressed at cell surfaces due to substitution at positions 86 in Ig Domain 0 and 182 in Ig Domain 1. J Immunol 2003, 171:6640-6649.

18. Carr WH, Pando MJ, Parham P: KIR3DL1 polymorphisms that affect NK cell inhibition by HLA-Bw4 ligand. J Immuno/ 2005, 175:5222-5229.

19. López-Larrea C, Segundo G, Martinez-Borra J: The role of HLAB27 polymorphism and molecular mimicry in spondyloarthropathy. Mol Med Today 1998, 4:540-549.

20. Kollnberger S, Bird L, Sun MY, Retiere C, Braud VM, McMichael A, Bowness $P$ : Cell-surface expression and immune receptor recognition of HLA-B27 homodimers. Arthritis Rheum 2002, 46:2972-2982

21. Kollnberger S, Bird LA, Roddis M, Hacquard-Bouder C, Kubagawa $\mathrm{H}$, Bodmer HC, Breban M, McMichael AJ, Bowness P: HLA-B27 heavy chain homodimers are expressed in HLA-B27 transgenic rodent models of spondyloarthritis and are ligands for paired Ig-like receptors. J Immuno/ 2004, 173:1699-1710.

22. Appel H, Kuon W, Kuhne M, Hulsmeyer M, Kollnberger S, Kuhlmann S, Weiss E, Zeitz M, Wucherpfennig K, Bowness P, Sieper $\mathrm{J}$ : The solvent-inaccessible Cys67 residue of HLA-B27 contributes to $\mathrm{T}$ cell recognition of HLA-B27/peptide complexes. J Immunol 2004, 173:6564-6573.

23. Liberatore C, Capanni M, Albi N, Volpi I, Urbani E, Ruggeri L, Mencarelli A, Grignani F, Velardi A: Natural killer cell-mediated lysis of autologous cells modified by gene therapy. J Exp Med 1999, 189:1855-1862.

24. Stewart-Jones GB, di Gleria K, Kollnberger S, McMichael AJ, Jones EY, Bowness P: Crystal structures and KIR3DL1 recognition of three immunodominant viral peptides complexed to HLA-B*2705. Eur J Immuno/ 2005, 35:341-351.

25. Snyder MR, Weyand CM, Goronzy JJ: The double life of NK receptors: stimulation or co-stimulation? Trends Immunol 2004, 25:25-32

26. Namekawa T, Snyder MR, Yen JH, Goehring BE, Leibson PJ, Weyand $\mathrm{CM}$, Goronzy JJ: Killer cell activating receptors function as costimulatory molecules on $\mathrm{CD} 4+\mathrm{CD} 28$ null $\mathrm{T}$ cells clonally expanded in rheumatoid arthritis. J Immunol 2000, 165:1138-1145.

27. Duftner C, Goldberger C, Falkenbach A, Wurzner R, Falkensammer B, Pfeiffer KP, Maerker-Hermann E, Schirmer M: Prevalence, clinical relevance and characterization of circulating cytotoxic CD4+CD28- T cell in ankylosing spondylitis. Arthritis Res Ther 2003, 5:R292-300.

28. Schirmer M, Goldberger C, Wurzner R, Duftner C, Pfeiffer KP, Clausen J, Neumayr G, Falkenbach A: Circulating cytotoxic CD8(+) CD28(-) T cells in ankylosing spondylitis. Arthritis Res 2002, 4:71-76.

29. Yen JH, Moore BE, Nakajima T, Scholl D, Schaid DJ, Weyand CM, Goronzy JJ: Major histocompatibility complex class I-recognizing receptors are disease risk genes in rheumatoid arthritis. $J$ Exp Med 2001, 193:1159-1167.

30. Martens PB, Goronzy JJ, Schaid D, Weyand CM: Expansion of unusual $\mathrm{CD}^{+} \mathrm{T}$ cells in severe rheumatoid arthritis. Arthritis Rheum 1997, 40:1106-1114.

31. Dulphy N, Rabian C, Douay C, Flinois O, Laoussadi S, Kuipers J, Tamouza R, Charron D, Toubert A: Functional modulation of expanded $\mathrm{CD}^{+}$synovial fluid $\mathrm{T}$ cells by NK cell receptor expression in HLA-B27-associated reactive arthritis. Int Immunol 2002, 14:471-479. 